SERGEJ TEŽAK, Ph.D.

E-mail: sergej.tezak@uni-mb.si

University of Maribor, Faculty of Civil Engineering

Smetanova 17, SI-2000 Maribor, Slovenia

RATKO ZELENIKA, Ph.D.

E-mail: zelenika@efri.hr

University of Rijeka, Faculty of Economics

Ivana Filipovića 4, HR-51000 Rijeka, Croatia

DRAGO SEVER, Ph.D.

E-mail: drago.sever@uni-mb.si

University of Maribor, Faculty of Civil Engineering

Smetanova 17, SI-2000 Maribor, Slovenia
Traffic Infrastructure

Preliminary Communication

Accepted: Feb. 24, 2010

Approved: May 17, 2011

\title{
MODEL OF SUSTAINABLE GROWTH AND DEVELOPMENT OF THE CABLEWAY TRANSPORT SYSTEM IN SLOVENIA
}

\section{ABSTRACT}

The cableway transport system is very important for the Slovenian tourist economy. Within the Slovene transport system, the cableway transport subsystem has a specific role because it allows and ensures access to regions which are difficult to access or completely inaccessible by other transport subsystems owing to the configuration of the area. The quality and development of transport services are directly linked to the introduction of new cableways. New technical achievements, which are nowadays used in cableways, all provide greater capacity and higher speed of cableways, which, however, results in their higher maintenance and exploitation costs.

The cableway transport system is being developed in Slovenia, but not on principles of sustainable development. This paper presents a model of sustainable growth and development of the cableway transport system in Slovenia based on which it is possible to determine assumptions for future growth so that the Slovene cableway transport system would approach standards of such highly developed systems. The new model includes ten essential elements of this system for which growth rates were calculated.

\section{KEY WORDS}

cableway transport system, cableways, econometrics, growth matrix, sustainable growth, winter tourism, mountain tourist centre

\section{INTRODUCTION}

Due to its specific characteristics and geographical position, Slovenia has numerous advantages for successful international affirmation - according to arguments of different professions, mostly in the area of transport services as well as in the area of tourism. Slovenia offers many different tourist possibilities among which the emphasis is on ski tourism in which a modern cableway transport system has an important role. For a high-quality offer, better cost-effectiveness and competition, continuous and optimal care for secure action and quality of all activities related to the management and maintenance of complex cableway transport systems is essential.

In accordance with the issues of research, the problem of research is determined: Although for many decades cableway transport in Slovenia has been intensely developed, there is still not enough attention dedicated to the scientifically established sustainable growth and development, which implies numerous transport and economic unfavourable consequences.

The problem of research has set up a framework for defining the project task: to research and establish the relevant characteristics of cableway transport, to analyse and evaluate the degree of development of the cableway transport in Slovenia and to propose a model of sustainable growth and development of the cableway transport system in Slovenia.

The problem and subject of research have determined performances for putting forward a scientific hypothesis: explicit, implicit, disciplinary and multidisciplinary knowledge and cognition about technical, technological, organizational, environmental, economic, legal, managerial regulations, principles, legalities, elements of cableway transport create a scientific paradigm for the proposal of a new model of sustainable growth and development of the cableway transport system in Slovenia that would enable a production of secure, high-quality, rational, competitive, profitable...services, sustainable growth and development of the cableway transport as an exceptionally 
important subsystem of the Slovenian transport and economic system.

\section{CABLEWAY TRANSPORT IN FOCUS OF THE TRANSPORT AND ECONOMIC SYSTEM OF SLOVENIA}

For the economic and any other development of an area, whether on the local, regional or governmental level, developed transport is an important and fundamental condition. The cableway transport system in the economic sense has an important role because it is one of the prerequisites for tourist transport flow in mountain areas. The activity of passenger transportation in cableway installations within the economic system is classified into two important industrial branches - transport and tourism [1].

\subsection{Concept and types of cableway transport}

Cableway transport is carried out by cableways that enable fast and relatively simple access to more sloping terrain in which various obstacles such as deep gorges, canyons, valleys, rivers, marshes and similar do not represent obstructions significant for transport availability.

Cableways are divided into [1]:

- funicular railways;

- aerial cableways, which serve for the transportation of passengers or freight above terrain. Aerial cableways are classified into:

- reversible cableways (reversible aerial ropeways);

- unidirectional aerial ropeway (gondola lifts, chairlifts) that are divided into:

- chairlifts with fixed grips;

- chairlifts with detachable grips;

- Ski tows.

\subsection{The mission of cableway transport in the transport system}

Transport as a system may be defined by a general system theory. Individual transport branches are defined as subsystems of the entire transport system and may be analysed via mutual connection and the influence of technics, technology, organization, economy, law, ecology, research and education. An individual transport branch may be proclaimed an independent transport system that again has its own subsystems. That way the cableway transport system (from the technical-technological viewpoint) is divided into subsystems: aerial cableways, funicular railways and ski tows. In addition to the roadway, railway and pipeline transport subsystem, the cableway transport subsystem is classified into the land transport system.

\subsection{Cableway transport - an important factor for the development of the economic system}

In observation of the influence of different branches and situations, that is, the effect of the whole economic system on the state and activity of sportstourist centres, a high degree of correlation and synergic effects has been determined. The most influential branches are those of agriculture and forestry, civil-engineering, industry, craft industry, trade, hotel and catering industry and tourism. These branches of economy have direct or indirect influence on the activity and development of sports-tourist centres. The most important role of sports-tourist centres is precisely in the stimulation of the hotel and catering industry and tourism. The other economic branches (craft industry - small businesses ...) are only supplementary sectors for higher quality of sports-tourist centre activities. The development of individual elements of sports-tourist centres is related to and depends on the development of individual economic branches (e.g., industry, civil engineering ...).

\section{ANALYSIS AND EVALUATION OF THE DEVELOPMENT STAGE OF THE CABLEWAY TRANSPORT SYSTEM IN SLOVENIA}

The following cableways operate regularly in Slovenia $^{1}$ : 3 reversible aerial ropeways, 2 funicular railways, ${ }^{2} 3$ gondola lifts - one of them has all the elements of unidirectional aerial ropeway, 4 six-seat chairlifts with detachable grips, 2 four-seat chairlifts with detachable grips, 9 four-seat chairlifts with fixed grips, 3 three-seat chairlifts with fixed grips, 27 twoseat chairlifts with grips, 7 one-seat chairlifts with fixed grips, 156 ski tows and 14 ski tows. Thus, it is a total of 230 different cableways that are in operating condition. But on the Slovenian territory there is a larger number of ski tows that are not at the moment in operating service. So, in the year 1998 in the Republic of Slovenia altogether 267 cableways were registered [2].

\subsection{Legal framework of cableway transport}

In the year 2009 Slovenia was situated, with regard to the law on cableway installations or cableway legislation, at the end of the transition from the old cableway legal practise towards a new and more modern one that is in force in the member states of the European Union.

The first step in the sense of modernity was the adoption of the Cableway Installations Designed for the Transport of Persons Act [3], harmonized with the Directive 2000/97/ES - European Directive on Cable- 
way Installations Designed to Carry Persons [4]. In the field of cableway transport in Slovenia the following legal acts apply:

- Regulation on cableway installations designed for the transport of persons, [5];

- Regulation on technical requirements for funicular railways, [6];

- Regulation on the professional training of personnel for work on cableways, [7];

- Ordinance on concessions for existing cableways [8];

- List of titles and references of harmonised standards related to cableway installations [9].

The old Regulation is still in force in Slovenia, which contains specific norms and standards used for cableway installations - Regulation on cableways and ski tows, that should be harmonised with the Acquis Communitaire (community acquis of the European Union).

The Technical Committee CEN/TC 242 has already created final versions of the standards - Safety requirements for cableway installations designed to carry persons that have been in force in Slovenia from the year 2007. There are altogether 23 standards and 2 safety recommendations for cableways for the transportation of persons.

\subsection{Major locations of cableways on the territory of Slovenia}

The cableway on the territory of Slovenia can be found on 80 or so $^{3}$ different locations, that is, at the same number of sports-tourist centres. In Slovenia there are few high mountain ski complexes (Vogel, Kanin and Krvavec are 1,800 meters altitude), which have better natural conditions than the lower ones (lower temperatures, more natural snow and longer winter season).

Equipping the lower mountain sports-tourist centres with devices for the production of additional (artificial) snow classifies these centres into winter competitive ones as well, especially due to the great advantage of their location in the vicinity of larger urban areas and in anyway good accessibility by private transport (Mariborsko Pohorje, Rogla, Stari Vrh, Krvavec...).

\subsection{Review of the cableway infrastructure in Slovenia}

Total capacity of the cableway transport system in Slovenia in the year 2007 was 178,214 persons per hour. According to the criteria of total capacity, accessible aerial ropeways have barely $3.3 \%$ of the total ca-

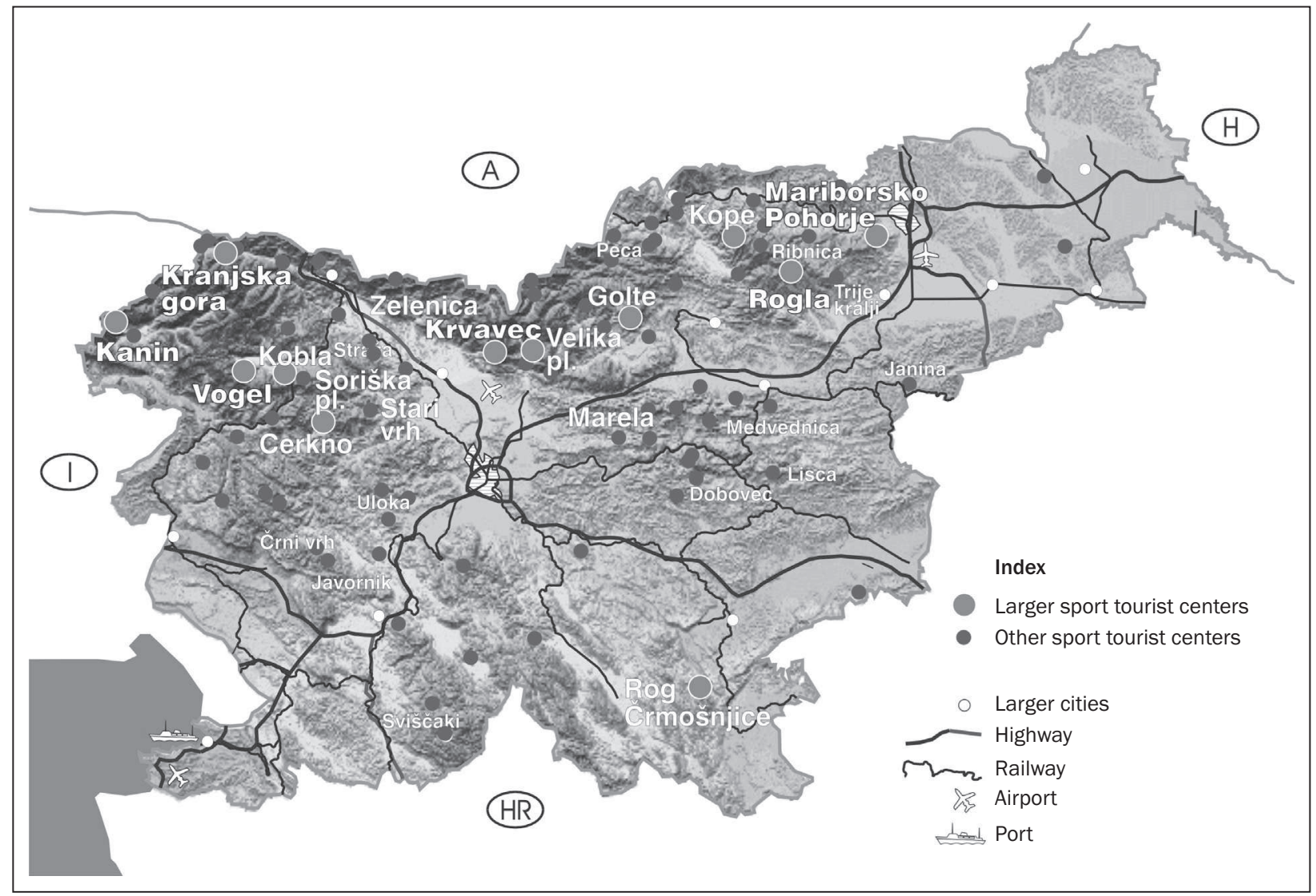

Figure 1 - Locations of cableways in Slovenia

Source: LIPIČNIK, M., SEVER.D et al.: Razvoj žičniškega prometnega sistema Republike Slovenije, Faculty of Civil Engineering, Maribor, 1999 


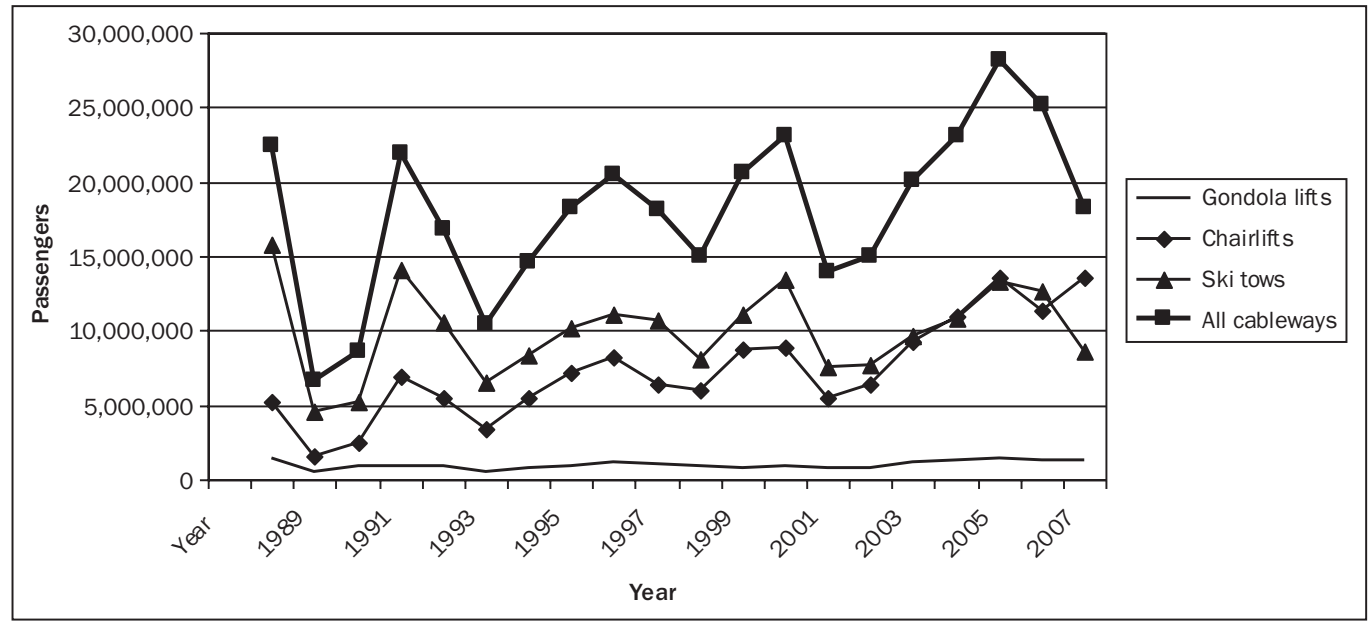

Graph 1 - Passengers transported by cableways in Slovenia from the year 1988 until 2007 Source: Bureau of Statistics of the Republic of Slovenia, 2009

pacity of all cableway installations. A small part, only $3.1 \%$, of these cableways ( 7 cableways) of the total number of all cableways therefore, do not provide sufficient capacity for carrying out the modern activity of public cableway passenger transport to locations of sports-tourist centres or at them. The largest capacity with regard to the total number of installations (52 cableways) have chairlifts (their share is $22.8 \%$, and they can transport $35.6 \%$ of all passengers). A smaller capacity, with regard to the number of installations have ski tows of which $74.12 \%$ (169 ski tows) can transport $61.1 \%$ of all passengers or potential users.

The average age of the cableway transport infrastructure in the Republic of Slovenia is 25 years. The average age of the oldest ski tows is 28.2 years, of available cableways (reversible aerial ropeways, unidirectional aerial ropeways and funicular railways) it is 21 , and the average age of the youngest chairlifts is 19.5 years.

\subsection{Analysis of the cableway passenger transport system in Slovenia}

The volume of cableway transport is in very strong correlation with the weather characteristics of each winter season because the largest number of cableway installations is in direct function of the skiing tourism. What influences most the number of transported passengers is the thickness of the snow layer and the number of days when it is possible to ski (days with satisfactory snow circumstances). Most passengers, i.e. $28,209,000$ of them were transported in the year 2005. Graph 1 shows that the number of passengers transported by chairlifts in the past years has reached and exceeded the number of passengers transported by ski tows (this indicates an expeditious modernization of the cableway system in Slovenia with cableways of better capacity and more favourable chairlifts for skiers).

\section{PROPOSAL FOR A MODEL OF SUSTAINABLE GROWTH AND DEVELOPMENT OF THE CABLEWAY TRANSPORT SYSTEM IN SLOVENIA}

The cableway transport system acts as a homogenous part of the transport system of the Republic of Slovenia and is composed of subsystems which are mutually connected and influence the performance of the entire system. Since the analysis of the existing state has shown certain weaknesses of the cableway transport system in Slovenia in the sense of outdated cableway infrastructure, the measured operational quality of the cableways (occurrence of malfunctions) [10], which is influenced by the maintenance and exploitation of cableways, there is a possibility to propose a model of the cableway transport system. The aim of the new model of the cableway transport system lies in increasing the quality of the cableway transport system in several elements - subsystems.

\subsection{Determination of the paradigm of the model of sustainable growth and development of the cableway transport system}

It is assumed that the cableway transport system is divided into $n$ mutually dependable subsystems, which will be mathematically treated as elements of the model of cableway system. The state of the cableway transport system at a specific moment may be written as:

$S=f\left(y_{1}, y_{2}, y_{3}, \ldots, y_{n-1}, y_{n}\right)$

$y_{1}, y_{2}, \ldots, y_{n}$ - values of the individual element of the model of cableway transport system (e.g., such as input, parameter, etc.) 
If over time the state of the cableway system changes, then the values of its individual elements also change. The input growth of the subscript i element of the cableway system is [11]

$\Delta y_{i t}=y_{i t}-y_{i . t-1}$

$y_{i t}$ and $y_{i, t-1}$ - values of individual element of the model of the cableway system subscript $i$ element $(i=1, \ldots, n)$ in the period $t$ and $t-1$.

The indirect growth rate of the subscript $i$ element in relation to the subscript $j$ element is defined as the relation of input growth of the subscript $i$ element of the cableway system, $\Delta y_{i t}$ and input value of the subscript $j$ element of the cableway system in period $t$ :

$r_{i j t}=\frac{\Delta y_{i t}}{y_{i t}} \quad i, j=1, \ldots, n . \quad y_{i . t-1} \neq 0$

Indirect growth rates may be expressed in the form of a matrix of growth (change) of elements of the cableway system:

$R_{t}=\left[\begin{array}{cccc}r_{11 t} & r_{12 t} & \cdots & r_{1 n t} \\ r_{21 t} & r_{22 t} & \cdots & r_{2 n t} \\ \vdots & \vdots & \ddots & \vdots \\ r_{n 1 t} & r_{n 2 t} & \cdots & r_{n n t}\end{array}\right] \quad t=1, \ldots, T$

where elements on the main diagonal indicate direct $(i=j)$, and the others $(i \neq j)$ indirect growth rates. Elements in the subscript $i$ row indicate growth of the input value in the subscript i element of the cableway system in relation to the other elements in function of the rationalization of production of services in cableway transport. Elements in the subscript $j$ column indicate growth of input values in all elements of the model in relation to the input value of the subscript $i$ element in period $t$. It follows from the above that each element in the growth matrix is represented by one row and one column with elements that express indirect or relative growth ratios. Therefore, the first row indicates input growth of the first element of the cableway transport system model in relation to other elements, and the first column indicates the growth of other elements in relation to the input of the first element. Other rows and columns correspond to other elements of the model of the cableway system in the function of increase in the quality of the cableway transport system and rational production of services in cableway transport. Indirect growth rates may also be defined in relation to the inputs of the subscript $j$ element model in period $t-1, \ldots$ :

$r_{i j t}^{\prime}=\frac{\Delta y_{i t}}{y_{j, t-1}} \quad i, j=1, \ldots, n$.

The relation between indirect growth rate (4.3) and (4.5) may be established through the following relations:

$r_{i j t}=\frac{r_{i j t}^{\prime}}{1+r_{j, j t}^{\prime}}$ and $r_{i j t}^{\prime}=\frac{r_{i j t}}{1-r_{j, j t}^{\prime}} \quad i, j=1, \ldots, n$.

The growth matrix (4.4) may also be determined through an external vector product. This method of determination is useful for a quick calculation of the growth matrix. The growth vector of elements of the model:

$\Delta y_{t}=\left(\Delta y_{1 t}, \ldots, \Delta y_{m . t}\right)$.

While the vector of reciprocal values of elements of the cableway system model is in the function of a rational production of services in cableway transport:

$\left(\frac{1}{y_{t}}\right)=\left(\frac{1}{y_{1 t}}, \ldots, \frac{1}{y_{n t}}\right) \quad i, j=1, \ldots, n . \quad y_{i . t-1} \neq 0$.

The external product of vectors of the elements of the model and vectors of reciprocal values may determine the growth matrix of the model of cableway transport system in the function of increasing the quality of the cableway transport system and rational production of services in cableway transport.

$R_{p t}=\Delta y_{t} \cdot\left(\frac{1}{y_{t}}\right)=\left[\begin{array}{c}\Delta y_{1 t} \\ \vdots \\ \Delta y_{m t}\end{array}\right] \cdot\left(\frac{1}{y_{t}}, \ldots, \frac{1}{\Delta y_{n t}}\right)$

When only the growth rates are under observation, then the growth of one element is expressed independently from the growth of others. Namely, when indirect growth rates are defined, that is the growth of the subscript $i$ element in dependence on the subscript $j$ $(i, j=1, \ldots, n)$, it is possible to define the structure of growth of elements and express all relations through the growth matrix in the system. Direct growth rates indicate the growth of a specific element of the model of sustainable growth and development of cableway transport from the year 2009 until 2020 in relation to the value of the concerned element in the year 2020 . At the same time by expressing direct and indirect growth rates it is possible to follow changes in the intensity of element growth, as well as their structural relations. The given properties of the growth matrix may be used for the model of the cableway transport system in Slovenia. In this matrix it is possible to determine the growth (change) of each individual element (subsystem) and correlation of change of all the elements in the model of cableway transport system in a specific time interval.

\subsection{Calculation of growth rates of elements of the model of sustainable growth and development of the cableway transport system in Slovenia}

Based on a special analysis [10], it is shown that for the development of the cableway transport system in Slovenia the following elements or subsystems are relevant and most important:

\subsubsection{Cableway infrastructure and technology}

Modernisation of the cableway infrastructure has great influence on the growth and competitiveness of 
the cableway transport system. The quantity is influenced by the total number of cableways, and the quality by the number of new or reconstructed cableways and these offer the structure of cableways. Research has established that the input for infrastructure and technology of cableway transport in the year 2009 had a value of 50 . The input is rather high due to great investments in the cableway transport system in Slovenia, where 3 gondola lifts, 21 chairlifts and 6 ski tows have been newly built or reconstructed in the past 17 years. The new expected technologies in cableway transport in Slovenia are detachable grips (faster chairlifts), hydraulic rope pulling machines (ropeways), ski tows speed regulation (degree-of-freedom speed control), use of chairs with covers (cover above chairlifts).

It is estimated that based on the use of these technologies and investments the input value for the year 2015 will grow to 65 and for the year 2020 to 80.

\subsubsection{Maintenance of cableways}

The introduction of new technologies has increased the number of different assemblies on cableways. Based on the analysis of occurrence of failures on the existing cableways it has been established that old cableways feature more failures because some of them are already worn out. Similarly, the newest cableways also have failures because of the beginner's mistakes of the personnel [10]. Based on the performed analyses the input value for the year 2009 may be estimated at 45. A fairly small input is due to the old cableways that prevail in Slovenia, which are more prone to failures and therefore require maintenance, and the complexity of this maintenance is not at such a high level. As for investments made in the cableway infrastructure, the number of cableway installations with detachable grips is expected to grow, which increases the maintenance requirements. It is estimated that the maintenance input in the year 2015 will have a value of 70 and in the year 2020 the value of 90 .

\subsubsection{Management and activity of cableway companies}

The merging of cableway companies in the Republic of Slovenia influences greatly the quality of management and activity of cableway companies. Therefore, the number of companies that engage in cableway transport is declining which in turn contributes to a better organisation. In the year 2009 the input value of management and activity of cableway companies may be estimated at 50, because larger cableway companies in Slovenia have the same owner and are organisationally related. In the year 2015, due to company mergers the input is estimated to increase to the value of 65. By the year 2020 it is expected that the introduction of the standard SIST EN 1386:2003 - “De- termination of the quality, aims measuring of services in public passenger transport" and introduction of the ISO standard for quality (standards of the group ISO 9000 and ISO 14 000) will increase the quality of services in cableway transport. That is why the input for the year 2020 will have a value of 95.

\subsubsection{Sustainable development of cableway transport}

Recently, sustainable development has had great importance in society. It is important that through their activities the humans leave the next generations the nature as they have received it at the beginning. This opinion has gained most importance since the impact of human on the climate change has been established. Due to the fact that the cableway transport system has small impact on gaseous emissions in the environment or small sound emissions, the cableway transport may be regarded as the most ecological one. In this sense the largest importance lies on cableways which can replace road transport to sports-tourist centres [12].

Until now the gondola lifts were constructed in Slovenia only because a road leading to the sports-tourist centre could not have been built (due to natural obstacles), and the impact on the environment by roads built leading to other centres was of secondary importance. That is why the input value for the sustainable development of cableway transport for the year 2009 was estimated at 25, and for the year 2015 at a value of 35. The construction of new cableways and connection of input centres with cableways and public transportation has been estimated, and therefore the input by the year 2020 will grow to 75 .

\subsubsection{Cableway transport law}

In the legal area much has been done in the past years for cableways in Slovenia and the European Union; therefore, an input value of 65 was estimated for the year 2009. By the year 2015 all legal regulations that have occurred due to the introduction of the European standards in Slovenia are expected to be harmonised. Therefore, it is estimated that the input for the year 2015 will have a value of 85 . By the year 2020 it is expected that legal regulations in the field of cableway transport of the European Union will be harmonised and that each member state of the European Union will demand certain special qualities for themselves and conform them to the European legal system. Therefore, an input value of 95 is estimated.

\subsubsection{Cableway information system}

Regarding snow conditions and the use of cableways in Slovenia, only 19 companies have web pages 
and 31 pieces of information are offered by Radio Slovenia. Systems for informing skiers at the ski centre itself mainly include information boards with fixed information, but the number of electronic message boards with possibilities to change information is still not large enough. The radio connections are mostly used for communication between employees, and there are fixed phones between the base stations (upper and lower). For the time being not one sports-tourist centre has central information (parameter) collection on cableway operation (except on the number of transported passengers), condition on ski-tracks and other facilities in the sports-tourist centre [13]. With regard to the aforementioned, it is estimated that the input value for cableway information system in the year 2009 amounted to only 30. By the year 2015 greater availability of information via web pages is expected and increasingly more cableways will have an automatic ticket control. In addition, a complete documentation is being prepared for the use of standards in digital form, which will be available to all cableway operators, and similarly a precise geographical (GIS-Geographical Information System) database on cableways and ski-tracks is also being created. Therefore, it is estimated that the input value for the year 2015 will grow to 75 . Likewise, the introduction of a central control system for cableway operation and utilisation and of their tracks at the sportstourist centres can be expected. Thus, an input value of 85 for the year 2020 is estimated.

\subsubsection{Human potential of cableway transport}

According to the valid regulations in Slovenia, cableways may be operated by those workers who have licences for operations chief of cableway or for maintenance and management of cableways, that is, if they have a license for cableway operator or attendant. For lead technical operator of cableways before the year 2007, a level IV degree of professional vocational education and license for technical operator of cableways was sufficient. Education lasted 22 hours, which from the viewpoint of very complex new cableway systems, were very few for a quality education. Therefore, it is expected that for the input of intellectual capital in cableway transport in the year 2009 the estimated value is only 25 . It is a fact that new cableways worth up to 10 million euro require more knowledge and responsibility for safe operation of cableways [12]. That is why the new Regulation on the professional training of personnel for work on cableways was accepted, [7], in which education according to the degree of professional training for lead operator depending on the cableway is predicted [14]. Education in the duration of 40 hours was predicted for each level of education. This education began at the end of/beginning of the year $2007 / 2008$ and that is why, by the year 2015 it shall be entirely used in practise. Therefore, the in- put value for the year 2015 is high and has a value of 80 . And by the year 2020 the input will grow to 95 because educated cableway transport engineers will actively participate in cableway traffic.

\subsubsection{Business policy of cableway companies}

The business policy of cableway companies can include: production policy, market policy, personnel policy, financial policy, environmental policy and development policy [15]. The most propulsive approach can be noticed in market policy, and in other segments of business policy there is no larger progress. This is best noticed in the development policy where only the cableway companies are responsible for modernization and everyone from the surrounding, including hotels and other tourist trades benefit from new cableways. That is why it is estimated that the input value for the year 2009 is only 30. It is estimated that in the following years there will be more progress in the development policy as well as personnel policy, therefore an input value of 50 is estimated for the year 2015. In the years after 2015 a more organized financial policy and development policy of companies is expected, especially concerning the funding of a new infrastructure. Investment in a modern cableway must be a project of the entire local community with all business entities involved. This problem will probably not be systematically solved so that an input value of only 80 is estimated for the year 2020.

\subsubsection{Logistic factors of cableway transport}

The logistic factors, which influence the operating of cableway companies, can include accessibility, several different accesses to sports-tourist centres, and close proximity of the public transport station. All have roads leading to sports-tourist centres, 12 sportstourist centres have direct access by bus, and only 2 sports-tourist centres have direct access by railway. In the future the accessibility of sports-tourist centres will not change that much, the improvement of road infrastructure will change the most, which is in many instances in very poor condition. Therefore, the input for the year 2009 is estimated at only 25. The greatest need will be for parking spaces if the capacity of cableways increases. As much as 17 largest ski centres in Slovenia dispose of 12,080 parking spaces, and construction of 6,800 more parking spaces is planned. From all aforementioned it is estimated that the input value for the year 2015 will increase to 45, and for the year 2020 to 65 . The input values in the year 2020 are very low considering the other subsystems because it is not expected that the reconstruction of the existing available roads to sports-tourist centres will be completed before the completion of the motorway program in Slovenia. 


\subsubsection{Other elements of cableway transport}

Among other subsystems of cableway transport all activities that influence the growth of cableway transport can be included. These subsystems are ski resorts and everything connected to them, production of additional snow, lighting of the ski resorts at night and preparation of the ski resorts. Free capacities for accommodation and hotel services also have great influence on the growth of cableway transport. From all the aforementioned, the input value for other subsystems and elements of cableway transport in the year 2009 may be estimated at a value of 50 . The high value is because larger sports-tourist centres already have good equipment for the production of additional snow and a sufficient number of capacities for overnight accommodation. In the years following up to 2015 the input will grow to a value of 80 , and by the year 2020 to a value of 95 .

Based on hypothetic values of elements of the cableway transport system model it is possible to determine the portion of each element - subsystem of cableway transport in the realization of the cableway transport system. If cableway transport and traffic appears as a subsystem of multimodal transport and traffic, it is possible to use other quantitative methods and models to optimize the business activity of cableway companies [16]. The model consists of values that quantify elements of the cableway transport system model in the year 2009 and assumed are the values for the year 2015 and 2020 (Table 1).

From the data in the table it is possible to determine the growth matrix of cableway transport for individual elements of the model of cableway transport system in the period 2009-2020 and growth rates of elements of the model of cableway transport system

Direct growth rates are indicated along the diagonal of the growth matrix, and the other values are indirect growth rates [17]. Direct growth rates for the year 2020 indicate growth of a specific element of the model from the year 2009 to 2020 compared to the same element in the year 2020. Intellectual capital in cableway transport has the highest growth of $74 \%$ because the input value for the year 2009 was low, and for the year 2020 the highest. Sustainable development of cableway transport has the second highest growth of $67 \%$ because in the year 2009 the input value of this element was very low at 25 . The element of cableway transport law has the lowest direct growth rate since the input value for the year 2009 was very high and cannot therefore grow as much (32\%) by the year 2020.

For comparison, the growth matrix was made for the year 2015, where it is clear that intellectual capital in cableway transport has again the maximum direct growth rate 69\%. For the year 2015 the Cableway information system has the second highest growth in value of $60 \%$. Cableway infrastructure and technology, and management and activity of cableway companies are two elements which have the lowest direct growth of rate $23 \%$ by the year 2015 .

For indirect growth rates it is evidently clear that the highest growth of intellectual capital is expected in relation to the influence of logistic factors on the operation of cableway companies that has an indirect growth rate value of $108 \%$. This is because no new investment in the existing motorway infrastructure is expected until the year 2020, and concerning intellectual capital, much will change by the year 2020 - necessary higher professional education for technical leaders of cableway companies and additional professional training at the engineering assembly in Slovenia. The following highest indirect growth rate of a value of $93 \%$ is the growth of intellectual capital compared to the sustainable development of cableway transport, and the third growth rate in line is the intellectual capital growth compared to the infrastructure and technology of cableway transport that has a value of $88 \%$.

Table 1 - Element values of the cableway transport system

\begin{tabular}{||l|c|c|c|c|c||}
\hline \multirow{2}{*}{$\begin{array}{c}\text { Elements of the new model of cable- } \\
\text { way transport in Slovenia }\end{array}$} & \multicolumn{2}{c|}{ Input value $y_{i t}$} & \multicolumn{2}{c||}{ Growth } \\
\cline { 2 - 7 } & 2009 & 2015 & 2020 & $\Delta y_{i, 2015}$ & $\Delta y_{i, 2020}$ \\
\hline \hline 1. Cableway infrastructure and technology & 50 & 65 & 80 & 15 & 30 \\
\hline 2. Maintenance of cableways & 45 & 70 & 90 & 25 & 45 \\
\hline 3. Management and activity of cableway companies & 50 & 65 & 95 & 15 & 45 \\
\hline 4. Sustainable development of cableway transport & 25 & 35 & 75 & 10 & 50 \\
\hline 5. Cableway transport law & 65 & 85 & 95 & 20 & 30 \\
\hline 6. Cableway information system & 30 & 75 & 85 & 45 & 55 \\
\hline 7. Human potential of cableway transport & 25 & 80 & 95 & 55 & 70 \\
\hline 8. Business policy of cableway companies & 30 & 50 & 80 & 20 & 50 \\
\hline 9. Logistic factors of cableway transport & 25 & 45 & 65 & 20 & 40 \\
\hline 10. Other elements of cableway transport & 50 & 80 & 95 & 30 & 45 \\
\hline
\end{tabular}


S. Težak, R. Zelenika, D. Sever: Model of Sustainable Growth and Development of the Cableway Transport System in Slovenia

Table 2 - Levels of growth of elements of the model of cableway transport system (year 2015)

\begin{tabular}{||l|c|c|c|c|c|c|c|c|c|c||}
\hline \hline & $\begin{array}{c}\text { Cab. } \\
\text { Inf. \& } \\
\text { tech.. }\end{array}$ & $\begin{array}{c}\text { Mainte- } \\
\text { nance }\end{array}$ & $\begin{array}{c}\text { Mana- } \\
\text { geme- } \\
\text { nt }\end{array}$ & $\begin{array}{c}\text { Sust. } \\
\text { dvlp. }\end{array}$ & $\begin{array}{c}\text { Cab. } \\
\text { tran. } \\
\text { Law }\end{array}$ & $\begin{array}{c}\text { Inf. } \\
\text { syst. }\end{array}$ & $\begin{array}{c}\text { Hum } \\
\text { poten- } \\
\text { tial }\end{array}$ & $\begin{array}{c}\text { Bus. } \\
\text { policy }\end{array}$ & $\begin{array}{c}\text { Log. } \\
\text { fact. }\end{array}$ & $\begin{array}{c}\text { Other } \\
\text { ele- } \\
\text { ments }\end{array}$ \\
\hline \hline Cab. Inf. \& tech. & $23 \%$ & $21 \%$ & $23 \%$ & $43 \%$ & $18 \%$ & $20 \%$ & $19 \%$ & $30 \%$ & $33 \%$ & $19 \%$ \\
\hline Maintenance & $38 \%$ & $36 \%$ & $38 \%$ & $71 \%$ & $29 \%$ & $33 \%$ & $31 \%$ & $50 \%$ & $56 \%$ & $31 \%$ \\
\hline Management & $23 \%$ & $21 \%$ & $23 \%$ & $43 \%$ & $18 \%$ & $20 \%$ & $19 \%$ & $30 \%$ & $33 \%$ & $19 \%$ \\
\hline Sust. development & $15 \%$ & $14 \%$ & $15 \%$ & $29 \%$ & $12 \%$ & $13 \%$ & $13 \%$ & $20 \%$ & $22 \%$ & $13 \%$ \\
\hline Cab. Tran. Law & $31 \%$ & $29 \%$ & $31 \%$ & $57 \%$ & $24 \%$ & $27 \%$ & $25 \%$ & $40 \%$ & $44 \%$ & $25 \%$ \\
\hline Inf. System & $69 \%$ & $64 \%$ & $69 \%$ & $129 \%$ & $53 \%$ & $60 \%$ & $56 \%$ & $90 \%$ & $100 \%$ & $56 \%$ \\
\hline Hum potential & $85 \%$ & $79 \%$ & $85 \%$ & $157 \%$ & $65 \%$ & $73 \%$ & $69 \%$ & $110 \%$ & $122 \%$ & $69 \%$ \\
\hline Bus. Policy & $31 \%$ & $29 \%$ & $31 \%$ & $57 \%$ & $24 \%$ & $27 \%$ & $25 \%$ & $40 \%$ & $44 \%$ & $25 \%$ \\
\hline Log. Fact. & $31 \%$ & $29 \%$ & $31 \%$ & $57 \%$ & $24 \%$ & $27 \%$ & $25 \%$ & $40 \%$ & $44 \%$ & $25 \%$ \\
\hline Other elements & $46 \%$ & $43 \%$ & $46 \%$ & $86 \%$ & $35 \%$ & $40 \%$ & $38 \%$ & $60 \%$ & $67 \%$ & $38 \%$ \\
\hline
\end{tabular}

Table 3 - Levels of growth of elements of the model of cableway transport system (year 2020)

\begin{tabular}{||l|c|c|c|c|c|c|c|c|c|c||}
\hline \hline & $\begin{array}{c}\text { Cab. } \\
\text { Inf. \& } \\
\text { tech. }\end{array}$ & $\begin{array}{c}\text { Mainte- } \\
\text { nance }\end{array}$ & $\begin{array}{c}\text { Mana- } \\
\text { geme- } \\
\text { nt }\end{array}$ & $\begin{array}{c}\text { Sust. } \\
\text { dvlp. }\end{array}$ & $\begin{array}{c}\text { Cab. } \\
\text { tran. } \\
\text { Law }\end{array}$ & $\begin{array}{c}\text { Inf. } \\
\text { syst. }\end{array}$ & $\begin{array}{c}\text { Hum } \\
\text { poten- } \\
\text { tial }\end{array}$ & $\begin{array}{c}\text { Bus. } \\
\text { policy }\end{array}$ & $\begin{array}{c}\text { Log. } \\
\text { fact. }\end{array}$ & $\begin{array}{c}\text { Other } \\
\text { ele- } \\
\text { ments. }\end{array}$ \\
\hline \hline Cab. Inf. \& tech.. & $38 \%$ & $33 \%$ & $32 \%$ & $40 \%$ & $32 \%$ & $35 \%$ & $32 \%$ & $38 \%$ & $46 \%$ & $32 \%$ \\
\hline Maintenance & $56 \%$ & $50 \%$ & $47 \%$ & $60 \%$ & $47 \%$ & $53 \%$ & $47 \%$ & $56 \%$ & $69 \%$ & $47 \%$ \\
\hline Management & $56 \%$ & $50 \%$ & $47 \%$ & $60 \%$ & $47 \%$ & $53 \%$ & $47 \%$ & $56 \%$ & $69 \%$ & $47 \%$ \\
\hline Sust. development & $63 \%$ & $56 \%$ & $53 \%$ & $67 \%$ & $53 \%$ & $59 \%$ & $53 \%$ & $63 \%$ & $77 \%$ & $53 \%$ \\
\hline Cab. Tran. Law & $38 \%$ & $33 \%$ & $32 \%$ & $40 \%$ & $32 \%$ & $35 \%$ & $32 \%$ & $38 \%$ & $46 \%$ & $32 \%$ \\
\hline Inf. System & $69 \%$ & $61 \%$ & $58 \%$ & $73 \%$ & $58 \%$ & $65 \%$ & $58 \%$ & $69 \%$ & $85 \%$ & $58 \%$ \\
\hline Hum potential & $88 \%$ & $78 \%$ & $74 \%$ & $93 \%$ & $74 \%$ & $82 \%$ & $74 \%$ & $88 \%$ & $108 \%$ & $74 \%$ \\
\hline Bus. Policy & $63 \%$ & $56 \%$ & $53 \%$ & $67 \%$ & $53 \%$ & $59 \%$ & $53 \%$ & $63 \%$ & $77 \%$ & $53 \%$ \\
\hline Log. Fact. & $50 \%$ & $44 \%$ & $42 \%$ & $53 \%$ & $42 \%$ & $47 \%$ & $42 \%$ & $50 \%$ & $62 \%$ & $42 \%$ \\
\hline Other elements & $56 \%$ & $50 \%$ & $47 \%$ & $60 \%$ & $47 \%$ & $53 \%$ & $47 \%$ & $56 \%$ & $69 \%$ & $47 \%$ \\
\hline
\end{tabular}

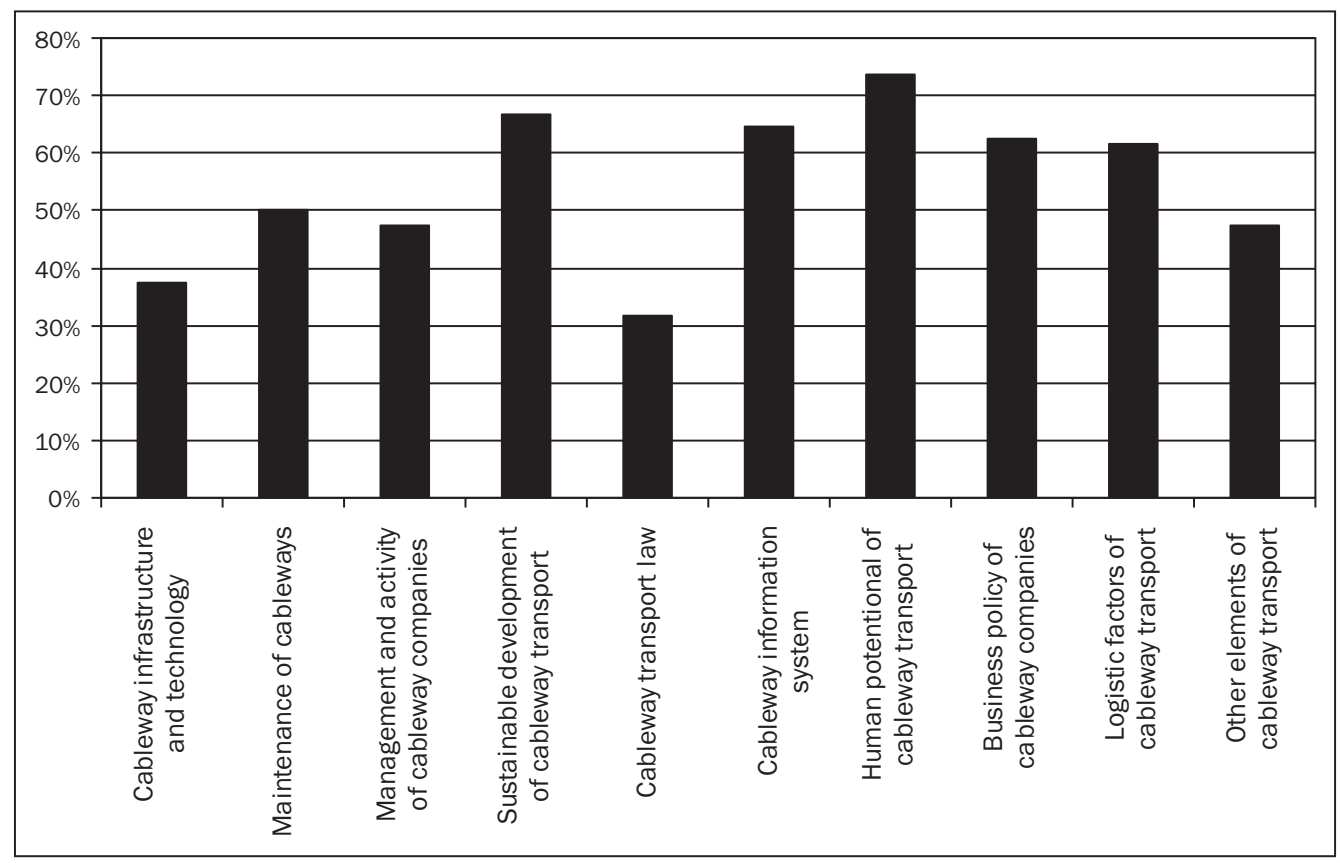

Graph 2 - Direct levels of growth of the cableway transport system from 2009 to 2020 


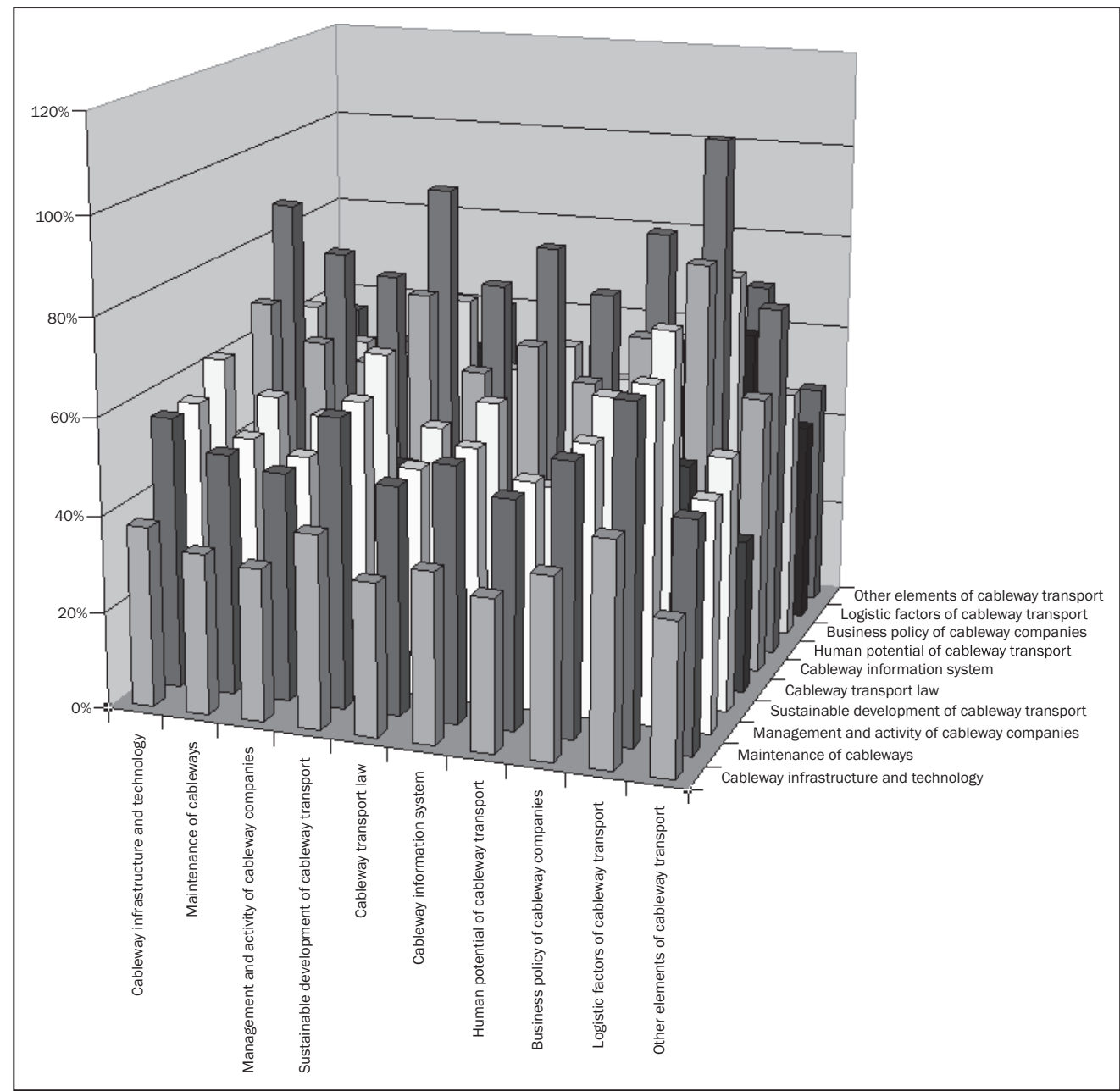

Graph 3 - Indirect levels of growth of the cableway transport system model from 2009 to 2020

It is very interesting, that indirect growth rates by the year 2015 can have higher values than indirect growth rates by the year 2020. Again, the highest growth is of intellectual capital in relation to the influence of logistic factors on the operation of cableway companies that has an indirect growth rate value of $122 \%$.

\subsection{Possibilities of the implementation of a model of sustainable growth and development of cableway transport in Slovenia}

\subsubsection{Measures and activities of sustainable operation of the model of cableway transport system}

The following measures and activities are proposed until the year 2020 in individual elements of the model of cableway transport system

- infrastructure and technology of cableway transport: reconstruction of existing cableways in sense of modernization, construction of new cableways, for example the connecting of multiple ski centres
(25 chairlifts, 1 gondola lift and 6 ski tows), increase of average use of cableways;

- maintenance of the cableway transport system: increase in maintenance work and resources for maintenance due to a more complex technique on cableways, more maintenance work is done by specialists for individual installations (specialised companies);

- organization of management and activity of cableway companies: organizational integration of a number of sports-tourist centres;

- sustainable development of cableway transport: check for new locations for skiing tracks in the sense of irreparable impact on nature and vegetation and check the construction of new cableways in function of availability throughout the year; the construction of one available gondola lift;

- cableway transport law: the recognition of new European standards in the Slovenian practise, supplement to the current legal system in cableway transport;

- information cableway system: investment in web marketing (skiing capacities and available overnight accommodation capacities and additional of- 
fers), investment in computer systems for the production of additional snow and supervision;

- intellectual capital in cableway transport: educating professional staff according to the Regulation on the professional training of personnel for work on cableways, which began in the year 2007 because the Seventh level (VII) of education (academy-institution of higher learning) is required for lead technical operator or his deputy, offers in regular education at faculties of technical sciences contents of cableway transport (technique and technology of cableway transport, cableway transport law);

- business policy of cableway companies: collaboration of the wider community for investments in cableways (mergers);

- influence of logistics factors on the operation of cableway companies: construction of a sufficient number of parking spaces compared to the new capacities of cableways (4,058 parking spaces), increase the number of passengers transported by public transport (additional non-regular bus routes, possibility of joint tickets for cableways and public transport);

- other subsystems and elements of the cableway system: construction of new skiing tracks (121 ha), construction of additional systems for the production of snow for all skiing tracks with complete infrastructure (dewatering pumps and water conservation), construction of new accommodation capacities and hotel-catering industry (1,300 beds), investments in equipment for the maintenance of skiing tracks, planning of new activities as an additional offer.

The above stated measures would enable an acceptable offer extension and thus influence the improvement in quality and better use of cableways (increase in the number of visitors and increase in the number of skiing days). For the determination of areas where the specific new measures would be of benefit, there is a possibility to use the methodology developed surrounding the project Redecon [18], where it is necessary to determine indicators, which are important for the sustainable development of the cableway transport system (number of passengers, number of cableways, distance to larger cities, transport time to the ski centre, accommodation capacities ....)

\subsubsection{Finance capital - factor of implementation of the model of sustainable growth and development of cableway transport}

The investment appraisal for the implementation of measures until the year 2020 totals $€ 242$ million. A considerable amount of capital should be invested into other subsystems and elements of the cableway system (additional production of snow, accommodation, skiing tracks, equipment for summer activities) and in cableway infrastructure. The most supported investment is in the systems for the production of additional snow, which could make possible a sufficient number of days for a reliable ski season. The consequences of the measures taken would be visible in synergic effects of the cableway transport system on other activities. Most noticeable would be changes in the tourism area (hotel-catering industry, accommodation, skiing, hiking, mountain biking and other recreational and sports activities) and in the field of industry (skiing equipment, textile industry, new innovation and technologies for the use of cableways in the summer time, industry of machines for the maintenance of ski tracks, development of information systems in cableway transport, devices for the production of additional snow). Since a lot of people spend their active vacation in the highlands in summertime, cableways should be built on those locations where operation would be safe in summer months. This can be achieved by locating cableways near thus far known resort points, which were accessible only by private transport, or providing activities near cableways that can be carried out off-season (new innovations). Due to the fact that the Slovenian mountain-tourist centres are relatively small compared to the European centres, with their cableway infrastructure they can serve as an access to pure and primal nature.

\section{CONCLUSION}

Within the new model of sustainable growth and development of cableway transport in Slovenia, based on research results, for the year 2009 the following elements were objectively evaluated:

- infrastructure and technology of the cableway transport,

- maintenance of the cableway transport system,

- management and activity of cableway companies,

- sustainable development of cableway companies,

- cableway transport law,

- information cableway system,

- human potentials of cableway companies,

- business policy of cableway companies,

- logistic factors of cableway transport,

- other elements of cableway transport,

for which direct and indirect growth rates for the year 2015 and 2020 were evaluated and calculated. In the period from 2009 to 2020 the growth of direct rates of $32 \%$ and a growth of indirect ones of $32 \%$ to $108 \%$ are expected. The expected growth of direct and indirect rates would enable modernization and rapid sustainable growth and development of the entire cableway transport system in Slovenia.

Concrete measures and activities were proposed, that would enable implementation of the model of sustainable growth and development of cableway transport in Slovenia. 


\section{Dr. SERGEJ TEŽAK}

E-mail: sergej.tezak@uni-mb.si

Univerza v Mariboru, Fakulteta za gradbeništvo

Smetanova 17, 2000 Maribor, Slovenija

Dr. RATKO ZELENIKA

E-mail: zelenika@efri.hr

Sveučilište u Rijeci, Ekonomski fakultet

Ivana Filipovića 4, 51000 Rijeka, Hrvatska

Dr. DRAGO SEVER

E-mail: drago.sever@uni-mb.si

Univerza v Mariboru, Fakulteta za gradbeništvo

Smetanova 17, 2000 Maribor, Slovenija

\section{POVZETEK}

\section{MODEL TRAJNOSTNE RASTI IN RAZVOJA ŽIČNIŠKEGA PROMETNEGA SISTEMA V SLOVENIJI}

Žičniški prometni sistem ima $v$ slovenskem turističnem gospodarstvu važno vlogo. V okviru prometnega sistema ima kot prometni podsistem specifično vlogo, saj nudi dostopnosti do krajev, ki so zaradi geografskih značilnosti težko dostopni ali nedostopni z drugimi prometnimi podsistemi. Novi tehnični dosežki, ki se uporabljajo na žičniških napravah omogočajo vse večje hitrosti in kakpacitete žičniških naprav, vendar je zaradi vedno več potrebno vlagat $v$ vzdrževanje in obratovanje žičniških naprav

Žičniški prometni sistem se $v$ Sloveniji razvija, ampak na načelih trajnostnega trazvoja. $V$ tem članku je predtsavljen model trajnostne rasti in razvoja žičniškega prometnega sistema v Sloveniji, na osnovi katerega je mogoče določiti predpostavke za bodoči trajnostni razvoj, da bi se slovenski žičniški promet približal standardom visoko razvitih žičniških sistemov. Novi model zajema 10 bistvenih elementov tega sistema, znotraj katerih so podane direktne in indirektne stopnje rasti razvoja.

\section{KLUUČNE BESEDE}

žičniški prometni sistem, žičniške naprave, matrica rasti, trajnostni razvoj, zimski turizem, gorsko turistični centri

\section{REFERENCES}

1. Source database on issued working permits for the operation of cableway installations - Ministry of Transport of the Republic of Slovenia, and database and permit for the operation of ski complexes - Faculty of Civil Engineering Maribor, situation January 2007.

2. Taken into account were funicular railways Ljubljanski Grad and Škocijanske jame.

3. Database on working permits for ski areas - Faculty of Civil Engineering Maribor, January 2007

\section{LITERATURE}

[1] Sever, D.: Some new methods to assure harmonisation ofsustainabledevelopmentofmountain resortsropeway. Promet - Traffic - Traffico (Zagreb), 2002, Vol. 14, No. 5

[2] Lipičnik, M., Sever, D. et al.: Razvoj žičniškega prometnega sistema Republike Slovenije, Fakulteta za gradbeništvo, Maribor, 1999
[3] Zakon o žičniških napravah za prevoz oseb / Cableway Installations Designed for the Transport of Persons Act (ZŽNPO), Uradni list Republike Slovenije, 126/2003

[4] Pravilnik o o žičniških napravah za prevoz oseb / Regulation on cableway installations designed for the transport of persons, Uradni list Republike Slovenije $36 / 2005$

[5] European Parliament and Council Directive relating to cableway installations designed to carry passengers 2000/9/EC, Brussels, 3 May 2000

[6] Pravilnik o tehničnih zahtevah za tirne vzpenjače / Regulation on technical requirements for funicular railways, Uradni list Republike Slovenije 126/2003

[7] Pravilnik o strokovnem usposabljanju osebja za obratovanje žičniških naprav / Regulation on the professional training of personnel for work on cableways, Uradni list Republike Slovenije 111/2006

[8] Uredba o koncesiji za obstoječe žičnice / Ordinance on concessions for existing cableways, Uradni list Republike Slovenije br. 103/2006

[9] Seznam standardov, katerih uporaba ustvarja domnevo o skladnosti žičniških naprav za prevoz oseb za nameravano uporabo / List of titles and references of harmonised standards related to cableway installations, Uradni list Republike Slovenije br. 57/2007

[10] Težak, S.: Model sustava žičarskog prometa u Sloveniji (Model of the cableway transport system in Slovenia), doctoral dissertation, University of Zagreb, Faculty of Transport and Traffic Sciences, May 2009

[11] Stojanović, D.: Matematičke metode u ekonomiji, dodatak matrica rasta, sedmo izmijenjeno i dopunjeno izdanje, Savremena administracija, Belgrade, 1988, p. 351

[12] Težak, S., Mavrin, I., Jurić, I.: Influence of modern cableways on the development of mountain tourist centres. Promet - Traffic - Traffico (Zagreb), 2005, Vol. 17, No 5

[13] Zelenika, R., Vukmirović, S., Mujić, H.: Computer-Supported Modelling of Multimodal Transportation Networks Rationalization, Promet - Traffic\&Transportation, University of Zagreb, Faculty of Transport and Traffic Sciences, Zagreb, 19, 2007, No 2, pp. 277-288.

[14] Zebec, S., Zelenika, R., Zečević, S.: Measuring the Intellectual Capital of International Carriers as Logistics Operators, Promet - Traffic\&Transportation, University of Zagreb, Faculty of Transport and Traffic Sciences, Zagreb, 19, 2007, No 3, pp. 103-114

[15] Zelenika, R., Zanne, M.: Poslovna politika u funkciji povećanja konkurentnosti pomorskih brodara. Naše more, 2008, No. 55

[16] Poletan Jugović, T., Jugović, A., Zelenika, R.: Multicriteria Optimisation in Logistics Forwarder Activities, Promet - Traffic\&Transportation, University of Zagreb, Faculty of Transport and Traffic Sciences, Zagreb, 19, 2007, No 3, pp. 145-153.

[17] Zelenika, R., Sever, R., Zebec, S.: Logistic operator fundamental factor in rational production of Services in multimodal transport, Promet - Traffic - Traffico, University of Zagreb, Faculty of Transport and Traffic Sciences, Zagreb, Vol. 17, 2005, No. 1, pp. 43-45

[18] Mesarec, B., Lep, M.: Combining the grid-based spatial planning and network-based transport planning. Ukio technol. ekon. vystym. (Spausd.), 2009, 15, 1 